\title{
Healthcare Quality and Justice Quality: Its Effects on Patient Satisfaction in the National Health Insurance Era
}

\author{
Nugroho Mardi Wibowo ${ }^{1}$, Woro Utari ${ }^{1}$, Abdul Muhith ${ }^{2}$, and Yuyun Widiastuti ${ }^{1}$ \\ ${ }^{1}$ Management Department, Universitas Wijaya Putra, Surabaya, Indonesia \\ ${ }^{2}$ Nursing Department, STIKes Majapahit, Mojokerto, Indonesia
}

\section{Abstract}

The purpose of this article is to explain the model of healthcare quality which consists of interaction, physical environment, outcomes, and justice quality associated with patient satisfaction by considering the patient's health condition before and after hospital treatment. The authors aim to examine the effect of healthcare quality (interaction, physical environment, outcome, and justice quality) on the patient satisfaction which is moderated by health conditions. Data were collected using a questionnaire with patients or patients' families as respondents in three Regional Public Hospitals in

Corresponding Author: Nugroho Mardi Wibowo nugrohomardi@uwp.ac.id

Received: 29 January 2019 Accepted: 27 February 2019 Published: 24 March 2019

Publishing services provided by Knowledge E

(c) Nugroho Mardi Wibowo et al. This article is distributed under the terms of the Commons Attribution License, which permits unrestricted use and redistribution provided that the original author and source are credited.

Selection and Peer-review under the responsibility of the $3 r d$ ICEEBA Conference Committee. East Java, Indonesia. The proposed research model consists of six constructs. They represent healthcare quality as follows: interaction quality (five variables); physical environment quality (four variables); outcome quality (three variables) and justice quality (six variables). There is also one construct that represents the patient's health condition (two variables - health conditions before and after treatment). Finally, there is one construct that represents patient's satisfaction (six variables). Testing the hypothesis model of this study used structural equation modeling (SEM) with the WarpPLS approach. The results of SEM analysis with the WarpPLS approach show that the goodness of fit statistics supported the model of healthcare quality-health conditions-patient's satisfaction. The results of hypothesis testing found that quality of physical environment, quality of outcomes, quality of justice were proven as constructs that could predict patient's satisfaction. Another important finding is the construct of health conditions proved to be a moderator on the effect of justice quality on patient's satisfaction.

Keywords: healthcare, health condition, patient's satisfaction, East Java, Indonesia

\section{Introduction}

Starting January 1, 2014 the Indonesian Government has implemented the National Health Insurance (JKN) system as mandate of the act number 40, 2004 concerning the National Social Security System (SJSN). This system is designed to ensure the availability of healthcare services quality for all Indonesians without exception. In the period of three years of JKN enactment, there were still many problems, especially 
in the absence of quality aspects in healthcare services. Based on [1], there are six dimensions of healthcare service quality that need to be realized by each country, namely effectiveness, efficiency, accessibility, safety, timeliness, and patient-centreness. In Indonesia the accessibility dimension is most often measured and claimed success among others is that all Indonesians can register for BPJS Health. But further access to health services is often a problem because of the limitations of health human resources and other resources. Other problems also exist in other quality dimensions such as effectiveness, efficiency, security, timeliness, and patient-centeredness, whose quality has never been measured.

As of June 1, $2017 \mathrm{JKN}$ participants reached 177.4 million participants with $61.4 \%$ were participants of the Contribution Assistance Recipients (PBI) who were none other than the poor and needy people whose premium payments came from ABPN and ABPD. This condition shows that JKN participants are dominated by the poor. Apart from the JKN participants from PBI (the poor) or not, ideally JK.4 participants as much as 177.4 million people must get quality health services in accordance with the mandate of the law. But the reality in the field shows that health services for the poor (PBI) and non-PBI are often not in line with expectations. This condition is supported by the results of the study by [2] found that health services provided to poor families often occur discrimination treatment that is detrimental to poor family patients. The hospital prefers to serve patients who pay cash after treatment rather than serving poor families or other JKN participants. Several JKN participant patients were known to be asked to buy drugs outside the hospital, subtly rejected at the hospital on the grounds that the required services were not covered by BPJS Kesehatan, until they were not optimally served in the hospital. If this incident continues, it is not impossible that participants will be disappointed and no longer trust the JKN system. Also in the Public Health Centre (Puskesmas), it is not uncommon for people to feel unsatisfactory services. The results of research by [3] in the Puskesmas in East Java showed that the procedures for puskesmas services, the clarity of information provided by the officers, the accuracy of prescription drugs, the quality of drugs received by patients, and the availability of medicines at the puskesmas had not been able to demonstrate an increase in patient satisfaction in the Puskesmas.

Based on the description above, it can be said that health services provided by providers in terms of hospitals and puskesmas in the era of JKN have not been able to meet the expectations of the community, especially JKN participants. At the level of health facilities (health facilities) both first level and referral there needs to be quality control of health services that not only maintain quality consistency but also pay attention to aspects of fair service as suggested by [4-7]. 
Healthcare quality and patient satisfaction have gained increasing attention in recent years [8]. Health service quality is an indicator that can be used to compare differences in health service programs [9], evaluate the quality of health services [10], and identify the needs of service aspects that can be developed to improve patient satisfaction [11].

Many studies emphasize patient care as an important tool for monitoring and at the same time improving service quality. Many hospitals adopt patient-centered service quality measures [12]. As a result, many studies analyze patient satisfaction using a broader range of measurements based on the definition of patient satisfaction.

Although the attention of researchers is aimed at the quality of health services, the amount of empirical research that analyzes the model as a whole is limited [8], and very few studies have examined this phenomenon from the point of view of inpatients, moreover inpatients who have completed care. There is evidence that some constructs form a quality model and overall patient satisfaction [11]. Some researchers have done a lot of cross-cultural research on health services and patient satisfaction [11], but there is still a research gap to develop and test models in a comprehensive manner to describe causal relationships between several constructs [11].

Healthcare model has been developed and applied to government institutions including hospitals and health centers is a model of excellent service based on the Decree of Minister of Administrative Reform No.63 of 2003 concerning the principles of excellent service. The excellent service model adopted the ServQual model developed by [13]. The excellent service model is still general and has not identified in detail the dimensions of justice.

The healthcare service quality model developed in this study is based on an integrated hierarchical model from [14]. According to [14], the overall perception of service quality is based on evaluation of three dimensions, namely the quality of interaction, the quality of the physical environment and the quality of outcomes. In addition, the health service quality model in this study also promotes the principles of justice. Based on this background, this study aims to develop a model of quality health care by basing integrated hierarchical models and service quality justly. This study also aims to analyze the effect of the quality of interaction, the quality of the physical environment, the quality of outcomes and quality on patient satisfaction which is moderated by the patient's health condition.

\section{Literature Review}




\subsection{Health care service quality}

Service quality has become a concept that is widely discussed in the service management literature [15]. Many researchers try to define the service quality construct and they agree that customers will evaluate service quality [16]. Clearly [17] states that service quality is an overall advantage of service perceived by customers. Thus the more superior a service perceived by the customer, the better the service quality perceived by the customer and vice versa.

Service quality has a close relationship with customer satisfaction [13]. However, both constructs have two important points of difference. First, service quality is only related to the assessment of service aspects, while satisfaction is not only related to the assessment of service aspects but also other factors such as price, image and other situational factors $[18,19]$. Second, service quality and customer satisfaction are a form of attitude from customers [13]. Service quality is a form of customer attitude based on cognitive while satisfaction is a form of affective customer behavior [20].

Many researchers have stated that service quality is a multidimensional construct but there is no agreement on how much and what dimensions of service quality [16]. [21] proposed a service quality model called the Nordic Model. This model focuses on three dimensions of service quality consisting of functional quality, technical quality and image [21]. Functional quality related to service outcomes while technical quality is related to service delivery process [14, 21]. On the other hand [13] proposed the SERVQUAL model. This model is called the American model emphasizing functional quality [14]. In detail [13] this service quality consists of five dimensions, namely responsiveness, empathy, assurance, tangible and reliability. Many researchers and practitioners use this American Model to measure service quality [22]. But this model has been widely criticized regarding its dimensional stability and its functional quality focus [23].

Both the American and Nordic models failed to explain that customer assessment of service quality is a complex process and customers tend to divide the service quality dimension into subdimensions [14]. This encourages other research to propose other service quality models [24]. [25] states that service quality consists of three levels: overall service quality, main dimensions, and sub dimensions. [25] is supported by [14] who found that the three main dimensions of service quality include interaction quality, outcome quality, and environment quality.

The assessment of service quality in this study refers to an integrated hierarchical model [14] and a fair service model [4, 7, 26-29]. Healthcare services are high-contact 
services requiring a lot of customer-employee interactions [30]. Assessment of perceptions of service quality in this study is based on an evaluation of four dimensions of service quality, namely interaction quality, physical environment quality, outcome quality and justice quality. The quality of interaction in high contact services such as health services has an important role in perceived service quality [31]. The service quality of the physical environment plays an important role in shaping the customer experience of the services it receives. The quality of the physical environment is commonly used to analyze the influence of the physical environment on the assessment of services by customers [30]. Outcome quality is technical quality and relevant customer attributes that are evaluated after service delivery [14]. In the healthcare industry, the outcome quality is the main determinant in the assessment of patient service quality perceptions.

\subsection{Justice quality}

There is a paradigm shift in service assessment of an organization by customers [29]. The tendency to evaluate organizational service by consumers does not depart from the assessment of service quality developed by [13] with a ServQual model and later developed by other researchers, but also assesses the aspect of organizational justice to deliver these services to all customers. According to [32], justice theory comes from the social psychology literature based on an individual's perception of justice in a situation or decision. [33] developed a conceptual framework based on justice theory to analyze the effect of failure and services repairmen to restaurant patrons. Their results show that justice based service has a significant effect on intensity of repeat visits. In other words, consumers want a fair service.

The justice concept was first used in marketing management relating to negligence of services provider and customer complaints [34]. According to [35], justice is ensured to the public in all aspects of life without compromise and reason. Justice is also interpreted as an evaluation of fair treatment of a person against another [6].

\subsection{Patient satisfaction}

According to [36], customer satisfaction is a customer evaluation after behaving in a certain time and place. [37] explain satisfaction as a result of a customer psychological assessment of direct experience. The satisfaction can be measured directly, for example through a pleasant/not pleasant feeling or satisfied/dissatisfied. Customer satisfaction is an emotional response to service attributes and service information is the basis to 
retain customers [37]. Satisfaction can be seen as a psychological state that is generated when customer's expectation is fulfilled or exceeds his or expectations and dispel the preconceived negative feelings about the consumption experience [38].

\subsection{Patient health conditions}

How many researchers have linked the health conditions of patients with patient satisfaction, but the results show inconsistent results [39]. [40] link between poor health conditions and dissatisfaction. Other medical care satisfaction studies show that people with poor health have stronger feelings in both directions (satisfied and dissatisfied) and that the most satisfied groups are those who have good health or those who suffer from chronic diseases [41]. [42] found that patients' health conditions were better predictors of satisfaction than doctors. Whereas [43] and [44] reported that health conditions are not related to satisfaction. [45] showed that patients with lower physical and mental health scores were significantly less likely to be satisfied.

\subsection{Model and hypotheses}

The model developed in the study is illustrated in Figure 1. There are six constructs in this research model, namely four constructs of healthcare quality, one construct of patient satisfaction and one construct of the patient's health condition. According to the Research Model, we formulate nine hypotheses:

H1. Interaction quality influences patient satisfaction

H2. Physical environment quality influences patient satisfaction

H3. Outcome quality influences patient satisfaction

H4. Justice quality influences patient satisfaction

H5. Patient health condition influences patient satisfaction

H6. Patient health condition moderates the effect interaction quality on patient satisfaction

H7. Patient health condition moderates the effect physical environment quality on patient satisfaction

H8. Patient health condition moderates the effect outcome quality on patient satisfaction 


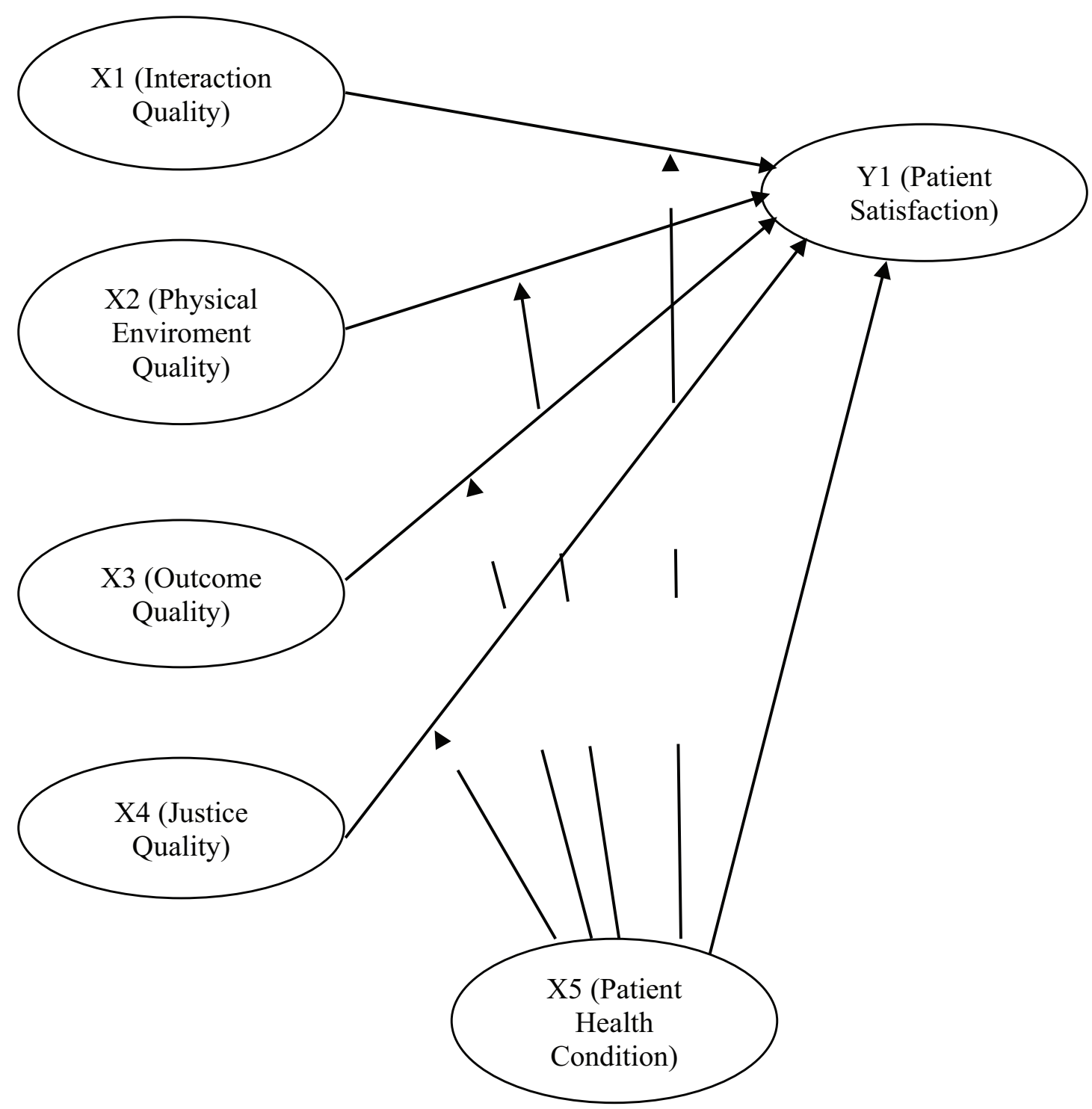

Figure 1: Research model.

H9. Patient health condition moderates the effect justice quality on patient satisfaction

\section{Research Methodology}

\subsection{Measure}

To ensure content validity, the indicators used in this research were obtained from the previous studies on healthcare service quality. Indicators of interaction quality, physical quality and outcome quality were obtained from $[14,25,30]$. The indicators of justice quality were obtained from [29] and [4]. The indicators of patient health condition were obtained from [39]. The indicators of patient satisfaction were obtained from [39]. Each indicators was measured using seven-point Likert scale ranging from 'strongly 
not sure/polite/precise/clean/complete/safe/efective/good/appropriate/satisfied (1)" to "strongly sure/polite/precise/clean/complete/safe/efective/good/appropriate/satisfied (7)."

To ensure construct validity, the indicators should have factor loading values above 0.5 [46]. The indicators with factor loading values below 0,5 should be removed. Appear in Table 2 indicator $X 4.2$ has a loading factor below 0.5 , so it must be removed. Then, reliability testing was carried out by using Cronbach alpha analysis.

From Table 2, it can be seen that each construct has an alpha Cronbach alpha values above the cut off value generally used, i.e. 0.6, except for patient health condition (X5). However, we still retained the contracts for patient health condition (X5) for a number of reasons. First, we obtained the scale from previous research [47]. Second, we followed the previous researchers (e.g. [24, 48]). Based on the procedure, we obtained 26 indicators used for this research as can be seen in Table 2 .

\subsection{Sample}

The population of this research is the patients at the Regional Public Hospital (RSUD) in East Java - Indonesia. The sample selection of RSUD in East Java by convenience sampling was based on the representation of cultural areas in East Java. Madura cultural area is represented by RSUD Dr. H. Slamet Martodirdjo, Pamekasan Regency, Mataraman culture is represented by RSUD Ngudi Waluyo Blitar Regency, and Arek culture is represented by RSUD Ibnu Sina, Gresik Regency.

The population of this research is the patients at the Regional Public Hospital (RSUD) in East Java - Indonesia. Pemilihan sampel RSUD di Jawa Timur dengan cara purposive sampling didasarkan pada keterwakilan daerah budaya di Jawa Timur. Daerah budaya madura diwakili oleh RSUD Dr. H. Slamet Martodirdjo Kabupaten Pamekasan, budaya mataraman diwakili oleh RSUD Ngudi Waluyo Kabupaten Blitar, dan budaya arek diwaliki RSUD Ibnu Sina Kabupaten Gresik.

Patient sampling was done by purposive sampling, i.e. patients who were hospitalized for at least 4 days. Data was collected through questionnaire surveys. Respondents in this study were patients and families of inpatients who were hospitalized for at least 4 days. Based on this, there were 241 respondents.

Fifty three point nine of respondents are female. The majority of the respondents are married (80.5\%). Further, the majority of the respondent's education background is primary school graduation (36.5\%). More completely, the demographic profile of the respondents can be seen in Table 2 . 
TABLE 1: Scale validity and reliability

\begin{tabular}{|c|c|c|c|}
\hline Construct & Indicators & $\begin{array}{l}\text { Factor } \\
\text { Loading }\end{array}$ & $\begin{array}{l}\text { Cronbach } \\
\text { Alpha }\end{array}$ \\
\hline \multirow[t]{5}{*}{ Interaction quality (X1) } & Doctor's polite behavior to patients (X1.1) & 0.786 & 0.830 \\
\hline & Nurses' polite behavior to patients (X1.2) & 0.786 & \\
\hline & $\begin{array}{l}\text { The accuracy of doctors providing healthcare } \\
\text { services (X1.3) }\end{array}$ & 0.732 & \\
\hline & $\begin{array}{l}\text { The accuracy of nurses' providing healthcare } \\
\text { services (X1.4) }\end{array}$ & 0.801 & \\
\hline & $\begin{array}{l}\text { The Interaction quality of patient-employee } \\
\text { (X1.5) }\end{array}$ & 0.753 & \\
\hline \multirow[t]{4}{*}{$\begin{array}{l}\text { Physical Environment } \\
\text { quality }(\mathrm{X} 2)\end{array}$} & $\begin{array}{l}\text { Neatness and cleanliness of the hospital } \\
\text { environment (X2.1) }\end{array}$ & 0.843 & 0.846 \\
\hline & $\begin{array}{l}\text { Cleanliness and comfort of hospital facilities } \\
\text { (X2.2.) }\end{array}$ & 0.878 & \\
\hline & Completeness of hospital facilities (X2.3) & 0.805 & \\
\hline & Hospital environment safety (X2.4) & 0.782 & \\
\hline \multirow[t]{3}{*}{ Outcome quality (X3) } & The effectiveness of drugs from doctors (X3.1) & 0.834 & 0.736 \\
\hline & $\begin{array}{l}\text { The condition of patients after treatment } \\
\text { (X3.2) }\end{array}$ & 0.809 & \\
\hline & Prioritizing the interests of patients (X3.3) & 0.783 & \\
\hline \multirow[t]{7}{*}{ Justice Quality (X4) } & $\begin{array}{l}\text { Conformity between the service results and } \\
\text { the patient wishes (X4.1) }\end{array}$ & 0.774 & 0.808 \\
\hline & There is no discrimination in service (X4.2) & 0.069 & \\
\hline & $\begin{array}{l}\text { Service compliance with regulations or } \\
\text { procedures (X4.3) }\end{array}$ & 0.734 & \\
\hline & The services provided are in the order (X4.4) & 0.742 & \\
\hline & $\begin{array}{l}\text { Doctor's attention to patient's complaints } \\
\text { (X4.5) }\end{array}$ & 0.761 & \\
\hline & Nurses' attention to patient's complaints (X4.6) & 0.828 & \\
\hline & $\begin{array}{l}\text { Providing information by doctors/nurses about } \\
\text { the patient's illness (X } 4.7)\end{array}$ & 0.773 & \\
\hline \multirow[t]{2}{*}{$\begin{array}{l}\text { Patient Health } \\
\text { Condition (X5) }\end{array}$} & $\begin{array}{l}\text { Conditions before getting service and care } \\
\text { (X5.1) }\end{array}$ & 0.814 & 0.491 \\
\hline & $\begin{array}{l}\text { Conditions after getting service and care } \\
\text { (X5.2) }\end{array}$ & 0.814 & \\
\hline \multirow[t]{6}{*}{ Patient Satisfaction (Y1) } & Patient satisfaction for hospital services (Y1.1) & 0.864 & 0.901 \\
\hline & $\begin{array}{l}\text { Patient willingness to go back to the hospital } \\
\text { (Y1.2) }\end{array}$ & 0.764 & \\
\hline & Patient satisfaction for hospital care (Y1.3) & 0.779 & \\
\hline & $\begin{array}{l}\text { Comfort of patients to recommend the } \\
\text { hospitals to friends (Y1.4) }\end{array}$ & 0.899 & \\
\hline & $\begin{array}{l}\text { Comparison of the hospital services with } \\
\text { other hospitals (Y1.5) }\end{array}$ & 0.838 & \\
\hline & $\begin{array}{l}\text { Patient willingness to recommend the hospital } \\
\text { to family/relatives/friends (Y1.6) }\end{array}$ & 0.759 & \\
\hline
\end{tabular}


TABLE 2: Respondent's demographic profile.

\begin{tabular}{l|c|}
\hline Characteristics & Percentage (\%) \\
\hline Sex & \\
\hline Male & 46.1 \\
\hline Female & 53.9 \\
\hline Age & \\
\hline S17 years old & 10.0 \\
\hline 18-25 years old & 12.0 \\
\hline 26-35 years old & 12.0 \\
\hline $36-45$ years old & 24.5 \\
\hline $46-55$ years old & 16.6 \\
\hline$\geq 56$ years old & 24.9 \\
\hline Marital Status & \\
\hline Married & 80.5 \\
\hline Single & 19.5 \\
\hline Education & \\
\hline Primary School & 36.5 \\
\hline Junior High School & 21.6 \\
\hline Senior High School & 33.2 \\
\hline Diploma & 0.8 \\
\hline Bachelor & 5.8 \\
\hline Other & 2.1 \\
\hline Occupation & 10.8 \\
\hline Students & 3.3 \\
\hline Government employee & 10.4 \\
\hline Private employee & 33.2 \\
\hline Entrepreneur & 29.9 \\
\hline Farmers/fishermen & \\
\hline Other & \\
\hline
\end{tabular}

\subsection{Data analysis}

To test the proposed research model, we use the analysis of structural equation modeling (SEM) with the WarpPLS approach. The use of the WarpPLS approach as a tool to test hypotheses in this study is to avoid the limitations associated with distributional properties, measurement levels, sample sizes, complexity models, identification and factor determinants [49]. The WarpPLS approach is also very well suited to the research objectives because the theoretical objectives are explaining and prediction and the research model is relatively complex and the phenomena studied are new or changing [50]. Data analysis was carried out using the WarpPLS 5.0 software. 


\section{Findings and Discussions}

\subsection{Assessment of the measurement model}

TABLE 3: Combined loading and cross-loadings.

\begin{tabular}{l} 
Indicator \\
$X 1.1$ \\
$X 1.2$ \\
$X 1.3$ \\
$X 1.4$ \\
$X 1.5$ \\
$X 2.1$ \\
$X 2.2$ \\
$X 2.3$ \\
$X 2.4$ \\
$X 3.1$ \\
$X 3.2$ \\
$X 3.3$ \\
$X 4.1$ \\
$X 4.3$ \\
$X 4.4$ \\
$X 4.5$ \\
$X 4.6$ \\
$X 4.7$ \\
$X 5.1$ \\
$X 5.2$ \\
$Y 1.1$ \\
$Y 1.2$ \\
$Y 1.3$ \\
$Y 1.4$ \\
$Y 1.5$ \\
Y1.6 \\
\hline
\end{tabular}

\begin{tabular}{|c|c|}
\hline $\mathbf{X 1}$ & $\mathbf{X 2}$ \\
\hline 0.786 & -0.051 \\
\hline 0.786 & 0.077 \\
\hline 0.732 & -0.304 \\
\hline 0.801 & -0.044 \\
\hline 0.753 & 0.315 \\
\hline-0.145 & 0.843 \\
\hline 0.007 & 0.878 \\
\hline 0.063 & 0.805 \\
\hline 0.083 & 0.782 \\
\hline 0.088 & 0.039 \\
\hline-0.064 & 0.069 \\
\hline-0.027 & -0.113 \\
\hline-0.069 & 0.132 \\
\hline-0.244 & 0.382 \\
\hline-0.095 & -0.036 \\
\hline 0.059 & -0.083 \\
\hline 0.094 & -0.308 \\
\hline 0.233 & -0.047 \\
\hline 0.031 & 0.089 \\
\hline-0.031 & -0.089 \\
\hline 0.067 & 0.038 \\
\hline-0.050 & -0.148 \\
\hline-0.040 & 0.066 \\
\hline 0.047 & 0.111 \\
\hline-0.024 & -0.018 \\
\hline-0.014 & -0.073 \\
\hline
\end{tabular}

\begin{tabular}{|c|}
\hline $\mathbf{X 3}$ \\
\hline 0.095 \\
\hline-0.306 \\
\hline 0.119 \\
\hline 0.081 \\
\hline 0.019 \\
\hline-0.224 \\
\hline 0.049 \\
\hline 0.053 \\
\hline 0.132 \\
\hline 0.834 \\
\hline 0.809 \\
\hline 0.783 \\
\hline-0.255 \\
\hline-0.156 \\
\hline-0.229 \\
\hline 0.246 \\
\hline 0.208 \\
\hline 0.159 \\
\hline 0.036 \\
\hline-0.036 \\
\hline 0.007 \\
\hline 0.437 \\
\hline-0.415 \\
\hline-0.068 \\
\hline-0.209 \\
\hline 0.289 \\
\hline
\end{tabular}

\begin{tabular}{|c|c|}
\hline $\mathbf{X 4}$ & $\mathbf{X 5}$ \\
\hline-0.049 & 0.242 \\
\hline-0.312 & -0.151 \\
\hline 0.251 & 0.093 \\
\hline 0.048 & -0.166 \\
\hline 0.082 & -0.010 \\
\hline 0.018 & 0.092 \\
\hline-0.427 & -0.070 \\
\hline 0.233 & -0.082 \\
\hline 0.220 & 0.064 \\
\hline 0.048 & 0.189 \\
\hline-0.110 & -0.016 \\
\hline 0.062 & -0.185 \\
\hline 0.775 & -0.079 \\
\hline 0.732 & 0.176 \\
\hline 0.744 & 0.088 \\
\hline 0.762 & 0.123 \\
\hline 0.828 & -0.259 \\
\hline 0.773 & -0.016 \\
\hline-0.126 & 0.814 \\
\hline 0.126 & 0.814 \\
\hline 0.158 & 0.085 \\
\hline-0.272 & 0.096 \\
\hline 0.384 & -0.206 \\
\hline-0.218 & 0.004 \\
\hline 0.097 & 0.049 \\
\hline-0.149 & -0.041 \\
\hline
\end{tabular}

\begin{tabular}{|c|c|}
\hline Y1 & P-value \\
\hline-0.323 & $<0.001$ \\
\hline 0.416 & $<0.001$ \\
\hline-0.234 & $<0.001$ \\
\hline 0.125 & $<0.001$ \\
\hline-0.003 & $<0.001$ \\
\hline-0.186 & $<0.001$ \\
\hline 0.100 & $<0.001$ \\
\hline 0.105 & $<0.001$ \\
\hline-0.020 & $<0.001$ \\
\hline-0.398 & $<0.001$ \\
\hline 0.244 & $<0.001$ \\
\hline 0.171 & $<0.001$ \\
\hline 0.076 & $<0.001$ \\
\hline 0.098 & $<0.001$ \\
\hline 0.408 & $<0.001$ \\
\hline-0.688 & $<0.001$ \\
\hline 0.102 & $<0.001$ \\
\hline 0.007 & $<0.001$ \\
\hline-0.486 & $<0.001$ \\
\hline 0.486 & $<0.001$ \\
\hline 0.864 & $<0.001$ \\
\hline 0.764 & $<0.001$ \\
\hline 0.779 & $<0.001$ \\
\hline 0.899 & $<0.001$ \\
\hline 0.838 & $<0.001$ \\
\hline 0.759 & $<0.001$ \\
\hline
\end{tabular}

Based on Table 3 it can be seen that all indicators have a factor loading value greater than 0.5. This means that all indicators meet convergent validity. All indicators also meet discriminant validity because the loading factor for all indicators is greater than cross loading.

From Table 4, it can be seen that each construct has a composite reliability coefficients values above the cut off value generally used, i.e. 0.7. Berarti semua contruct memenuhi reliabilities composite. It can be seen at the table that each construct has a Cronbach's alpha coefficients above the cut off value generally used i.e. 0.6 except for patient health 
TABLE 4: Composite reliability and Cronbach alpha.

Construct
Interaction Quality (X1)
Physical Environment Quality (X2)
Outcome Quality (X3)
Justice Quality (X4)
Patient Health Condition (X5)
Patient Satisfaction (Y1)

\begin{tabular}{|c|}
\hline $\begin{array}{c}\text { Composite } \\
\text { reliability } \\
\text { coefficients }\end{array}$ \\
\hline 0.880 \\
0.897 \\
\hline 0.850 \\
\hline 0.897 \\
\hline 0.797 \\
\hline 0.924 \\
\hline
\end{tabular}

$\begin{gathered}\text { Cronbach's alpha } \\ \text { coefficients }\end{gathered}$
0.830
0.846
0.736
0.862
0.491
0.901

condition. However, we still retained the contracts for patient health condition (X5) for a number of reasons. First, we obtained the scale from previous research [47]. Second, we followed the previous researchers (e.g. [24, 48]).

\subsection{Assessment of the structural model}

TABLE 5: Model fit and quality indices.

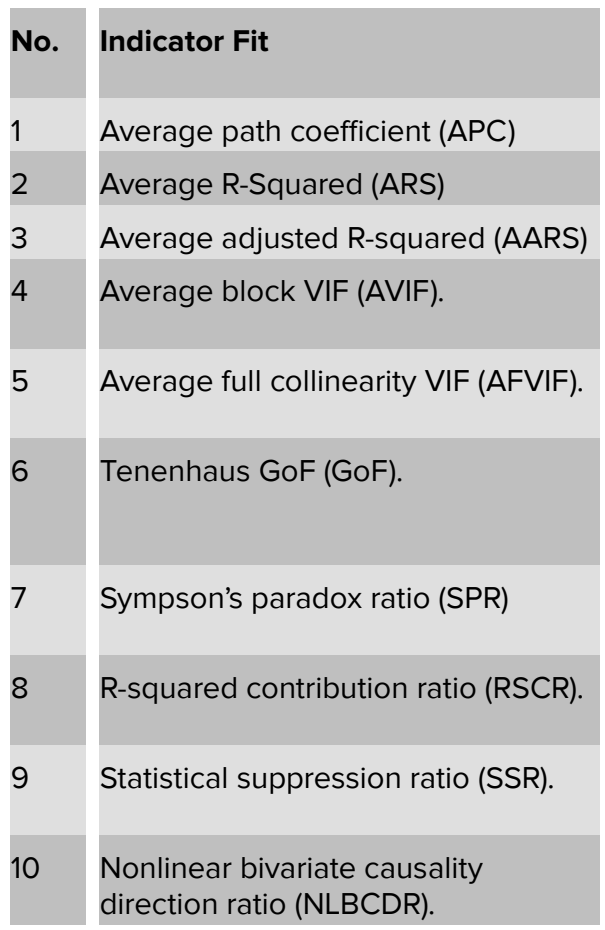

\begin{tabular}{|c|c|}
\hline Fit Criteria & Value \\
\hline$p<0.05$ & $0.119(p<0.015)$ \\
$p<0.05$ & $0.768(p<0.001)$ \\
\hline$p<0.05$ & $0.759(p<0.001)$ \\
\hline $\begin{array}{c}\text { Acceptable if }<= \\
5, \text { ideally }<=3.3\end{array}$ & 3.306 \\
\hline $\begin{array}{c}\text { Acceptable if }<= \\
\text { 5, ideally }<=3.3\end{array}$ & 3.426 \\
\hline $\begin{array}{c}\text { Small }>=0.1, \\
\text { medium }>=0.25, \\
\text { large }>=0.36\end{array}$ & 0.656 \\
\hline $\begin{array}{c}\text { Acceptable if }>= \\
0.7, \text { ideally }=1\end{array}$ & 0.778 \\
\hline $\begin{array}{c}\text { Acceptable if }>= \\
0.9, \text { ideally }=1\end{array}$ & 0.997 \\
\hline $\begin{array}{c}\text { Acceptable if }>= \\
0.7\end{array}$ & 1.000 \\
\hline $\begin{array}{c}\text { Acceptable if }>= \\
0.7\end{array}$ & 0.556 \\
\hline
\end{tabular}

\begin{tabular}{|c|}
\hline $\begin{array}{l}\text { Assessment of } \\
\text { Model }\end{array}$ \\
\hline Model Fit \\
\hline Model Fit \\
\hline Model Fit \\
\hline Model Fit \\
\hline Model Fit \\
\hline Model Fit \\
\hline Model Fit \\
\hline Model Fit \\
\hline Model Fit \\
\hline Not Model Fit \\
\hline
\end{tabular}

Table 5 shows that out of 10 indicators fit, 9 of them show a fit model. Based on the parsimony principle, it can be concluded that this research model belongs to the fit model category.

Based on Table 6 it can be seen that the quality of interaction (X1) has no effect on patient satisfaction (Y1). This is indicated by the path coefficient of 0.047 with a $p$-value of 
TABLE 6: Path coefficients.

Relationship between variable
Interaction Quality (X1) $\rightarrow$ Patient Satisfaction
(Y1)
Physical Environment Quality (X2 $\rightarrow$ Patient
Satisfaction (Y1)
Outcome Quality (X3) $\rightarrow$ Patient Satisfaction
(Y1)
Justice Quality (X4) $\rightarrow$ Patient Satisfaction (Y1)
Patient Health Condition (X5) $\rightarrow$ Patient
Satisfaction (Y1)
$X 5^{*} X 1 \rightarrow$ Patient Satisfaction (Y1)
$X 5^{*} X 2 \rightarrow$ Patient Satisfaction (Y1)
$X 5^{*} X 3 \rightarrow$ Patient Satisfaction (Y1)
$X 5^{*} X 4 \rightarrow$ Patient Satisfaction (Y1)

\begin{tabular}{|c|}
\hline $\begin{array}{c}\text { Path } \\
\text { coefficient }\end{array}$ \\
\hline 0.047 \\
\hline 0.130 \\
\hline 0.100 \\
\hline 0.512 \\
\hline 0.191 \\
\hline-0.023 \\
\hline 0.052 \\
\hline 0.012 \\
\hline 0.094 \\
\hline
\end{tabular}

\begin{tabular}{|l|l|}
\hline p-value & Result \\
\hline 0.230 & $H 1$ is not supported \\
\hline 0.020 & $H 2$ is supported \\
\hline 0.057 & $\begin{array}{l}H 3 \text { is supported in } p \leq \\
0.10\end{array}$ \\
\hline 0.001 & $H 4$ is supported \\
\hline 0.001 & $H 5$ is supported \\
\hline 0.358 & $H 6$ is not supported \\
\hline 0.206 & $H 7$ is not supported \\
\hline 0.426 & $H 8$ is not supported \\
\hline 0.071 & $\begin{array}{l}H 9 \\
\text { is supported in } p \leq\end{array}$ \\
\hline
\end{tabular}

0.230 greater than 0.05 . This condition reflects that changes in the quality of interaction have no impact on patient satisfaction. JKN patients see and feel that doctor's politeness in patients does not affect changes in patient satisfaction.

It is seen that the quality of the physical environment (X2) has an influence on patient satisfaction (Y1). The path coefficient is 0.130 with a $p$-value of 0.020 smaller than 0.05 . This illustrates that changes in the physical environment $(X 2)$ of the hospital have an impact on changes in patient satisfaction (Y1). JKN patients feel that changes in the physical environment can improve patient satisfaction.

Table 6 shows that the quality of outcomes (X3) has an influence on patient satisfaction (Y1). This result is indicated by the path coefficient of 0.100 with $p$-value 0.057 smaller than 0.10 . This condition reflects that the quality of outcomes (X3) has a contribution to improving patient satisfaction (Y1). The quality of the outcome is mainly on the indicator of the effectiveness of the drug from the doctor to control the condition of the patient which causes the patient to feel satisfied.

The same results are also the justice quality $(X 4)$. The findings of the study indicate that the quality of fair service has an influence on patient satisfaction (Y1). This is indicated by the path coefficient of 0.512 with a $p$-value smaller than 0.001 . This condition shows that equitable health services are something that is desirable for JKN patients. The hospital has provided health services with principles on the values of justice. The nurses have worked well by responding to patients' complaints about their illness. The doctor has also done the same thing. 
It appears in Table 6 that the health condition variable (X5) has an effect on patient satisfaction (Y1) with a path coefficient of 0.191 with $p$-value 0.001 smaller than 0.05 . These findings indicate that changes in the patient's health condition have an impact on patient satisfaction ( $\mathrm{Y} 1)$.

Interaction variables $X 5^{*} \times 1, X 5{ }^{*} \times 2$, and $X 5 * X 3$ have no effect on patient satisfaction variables (Y1) while $\mathrm{X} 5{ }^{*} \mathrm{X} 4$ has an influence on satisfaction variables. These results indicate that the patient's health condition variable (X5) proved to be positioned as a moderator variable the effect of fair service quality $(X 4)$ on patient satisfaction (Y1). Based on Table 6 the path coefficient of the effect of the $X 5{ }^{*} \times 4$ interaction variable on patient satisfaction ( $\mathrm{Y} 1$ ) is 0.094 with $p$-value 0.071 less than 0.10 . This means that the health condition variable has a role to strengthen the effect of fair service on patient satisfaction. Whereas in the path of the influence of the quality of interaction, the quality of the physical environment and the quality of outcomes on patient satisfaction, the health condition variable was not proven to be a moderator variable.

\section{Conclusions}

Hypothesis testing shows that the quality of the physical environment has an influence on patient satisfaction. This reflects that the environment and hospital facilities can influence the patient's perception to feel satisfied or dissatisfied. The better the clean and tidy the home environment, the patient feels more satisfied. In addition, if there is an increase in hospital facilities, patient satisfaction also increases. Some research results such as those conducted by [51-54] managed to identify that medical facilities are part of the quality dimension of inpatient services.

The results also found that outcome quality had an influence on poor satisfaction. This condition is reasonable, given that patients who seek treatment and are treated with ill health will expect to recover. When the patient's expectations are proven to heal or improve the patient's condition, then this will improve patient satisfaction. It could be that the patient's recovery was due to medication or rapid action given by the doctor.

Justice quality is proven that can affect patient satisfaction. The more equitable in health services in hospitals in the JKN era will have an impact on increasing patient satisfaction. This finding is in line with the research by [29] which found that informational and interactional justice had an impact on increasing patient satisfaction.

The results of hypothesis testing also concluded that patient health conditions have an influence on patient satisfaction. This finding supports the research of [42] who found that patients' health conditions were better predictors of satisfaction than doctors. It was 
proven that patient health condition as a moderator on the influence of justice quality on patient satisfaction. This means that justice quality will be able to increase patient satisfaction if the health conditions are getting better.

Testing other hypotheses shows that the quality of interaction has no effect on patient satisfaction. Patient health condition is not proven as a moderator on the influence of the quality of interaction, the quality of the physical environment and the quality of outcomes on patient satisfaction.

\section{Acknowledgment}

The authors would like to thank the Director of Research and Community Services, Ministry of Research and Higher Education for providing research funding to undertake this study.

\section{References}

[1] Ramadan, N. and Arafeh, M. (April 2016). Healthcare quality maturity assessment model based on quality drivers. International Journal of Health Care Quality Assurance, vol. 29, no. 3, pp. 337-350.

[2] Dalinjong, P. and Laar, A. (July 2012). The national health insurance scheme: perceptions and experiences of health care providers and clients in two districts of Ghana. Health Economics Review, vol. 2, no. 1, p. 13.

[3] Wibowo, N. M. (September 2013). Strategi pengembangan pelayanan rawat inap puskesmas berbasis service delivery system. EKUITAS J. Ekon. dan Keuang, vol. 17, no. 3, pp. 337-356.

[4] Nikbin, D., Ismail, I., Marimuthu, M., et al. (March 2012). Perceived justice in service recovery and switching intention. Management Research Review, vol. 35, no. 3/4, pp. 309-325.

[5] Kwun, O. and Alshare, K. A. (2007). The impact of fairness on user's satisfaction with the IS department. Journal of Management Information and Decision Science, vol. 10, no. 1, p. 47.

[6] Huang, J.-H. and Lin, C.-Y. (2005). The explanation effects on consumer perceived justice, satisfaction and loyalty improvement: An exploratory study. The Journal of American Academy of Business, vol. 7, no. 2, pp. 212-218.

[7] Bugg Holloway, B., Wang, S., and Beatty, S. E. (September 2009). Betrayal? Relationship quality implications in service recovery. Journal of Services Marketing, 
vol. 23, no. 6, pp. 385-396.

[8] Zineldin, M. (2006). The quality of health care and patient satisfaction: an exploratory investigation of the $5 \mathrm{Qs}$ model at some Egyptian and Jordanian medical clinics. International Journal of Health Care Quality Assurance Incorporating Leadership in Health Services, vol. 19, no. 1, pp. 60-92.

[9] Andaleeb, S. S. (May 2001). Service quality perceptions and patient satisfaction: A study of hospitals in a developing country. Social Science \& Medicine, vol. 52, no. 9, pp. 1359-1370.

[10] Badri, M., Dodeen, H., Al Khaili, M., et al. (2005). Development of the national inpatient satisfaction constructs and items for the United Arab Emirates. International Journal of Applied Health Studies, vol. 1, no. 3, pp. 1-22.

[11] Badri, M. A., Taher Attia, S., and Ustadi, A. M. (March 2008). Testing not-so-obvious models of healthcare quality. International Journal of Health Care Quality Assurance, vol. 21, no. 2, pp. 159-174.

[12] Hendriks, A. A. J., Oort, F. J., Vrielink, M. R., et al. (December 2002). Reliability and validity of the Satisfaction with Hospital Care Questionnaire. International Journal for Quality in Health Care, vol. 14, no. 6, pp. 471-482.

[13] Parasuraman, A., Zeithaml, V. A., and Berry, L. L. (1988). Servqual: A multiple-item scale for measuring consumer perc. Journal of Retailing, vol. 64, no. 1, p. 12.

[14] Brady, M. K. and Cronin, J. J. (2001). Some new thoughts on conceptualizing perceived service quality: A hierarchical approach. Journal of Marketing, vol. 65, pp. 34-49.

[15] Zahari Wan Yusoff, W., Ismail, M., and Shah Ali, A. (July 2010). Understanding the service provider perspective towards better service quality in local authorities. Journal of Facilities Management, vol. 8, no. 3, pp. 226-238.

[16] Clemes, M. D., Gan, C., Kao, T.-H., et al. (March 2008). An empirical analysis of customer satisfaction in international air travel. Innov. Mark., vol. 4, no. 2.

[17] Zeithaml, V. A. (July 1988). Consumer perceptions of price, quality, and value: A means-end model and synthesis of evidence. Journal of Marketing, vol. 52, no. 3, p. 2.

[18] Parasuraman, A., Zeithaml, V. A., and Berry, L. L. (January 1994). Reassessment of expectations as a comparison standard in measuring service quality: Implications for further research. Journal of Marketing, vol. 58, no. 1, p. 111.

[19] Zeithaml, V. A., Bitner, M. J., and Gremler, D. D. (2009). Services Marketing: Integrating Customer Focus Across the Firm (seventh edition). Boston: McGraw-Hill. 
[20] Wilcox, K., Roggeveen, A. L., and Grewal, D. (December 2011). Shall I tell you now or later? Assimilation and contrast in the evaluation of experiential products. Journal of Consumer Research, vol. 38, no. 4, pp. 763-773.

[21] Grönroos, C. (April 1984). A service quality model and its marketing implications. European Journal of Marketing, vol. 18, no. 4, pp. 36-44.

[22] Jen, W., Tu, R., and Lu, T. (March 2011). Managing passenger behavioral intention: An integrated framework for service quality, satisfaction, perceived value, and switching barriers. Transportation (Amst)., vol. 38, no. 2, pp. 321-342.

[23] Nagata, H., Satoh, Y., Gerrard, S., et al. (August 2004). The dimensions that construct the evaluation of service quality in academic libraries. Performance Measurement and Metrics, vol. 5, no. 2, pp. 53-65.

[24] Sumaedi, S., Yarmen, M., and Yuda Bakti, I. G. M. (November 2016). Healthcare service quality model: A multilevel approach with empirical evidence from a developing country. International Journal of Productivity and Performance Management, vol. 65, no. 8, pp. 1007-1024.

[25] Dabholkar, P. A., Thorpe, D. I., and Rentz, J. O. (December 1996). A measure of service quality for retail stores: Scale development and validation. Journal of the Academy of Marketing Science, vol. 24, no. 1, pp. 3-16.

[26] del Río-Lanza, A. B., Vázquez-Casielles, R., and Díaz-Martín, A. M. (August 2009). Satisfaction with service recovery: Perceived justice and emotional responses. Journal of Business Research, vol. 62, no. 8, pp. 775-781.

[27] Mattila, A. S. (December 2006). The power of explanations in mitigating the ill-effects of service failures. Journal of Services Marketing, vol. 20, no. 7, pp. 422-428.

[28] Ambrose, M., Hess, R. L., and Ganesan, S. (May 2007). The relationship between justice and attitudes: An examination of justice effects on event and system-related attitudes. Organizational Behavior and Human Decision Processes, vol. 103, no. 1, pp. 21-36.

[29] Wibowo, N. M., Widiastuti, Y., and Panglipursari, D. L. (2016). Justice-based health care service and repatronage intention of poor patient. Pertanika Journal of Social Science and Humanities, vol. 24, no. June, pp. 233-244.

[30] Lien, C., Wu, J.-J., Chen, Y.-H., et al. ( July 2014). Trust transfer and the effect of service quality on trust in the healthcare industry. Managing Service Quality: An International Journal, vol. 24, no. 4, pp. 399-416.

[31] Petzer, D. J., De Meyer, C. F., Svari, S., et al. (October 2012). Service receivers' negative emotions in airline and hospital service settings. Journal of Services Marketing, vol. 26, no. 7, pp. 484-496. 
[32] Ting, C.-Y. and Yu, T.-K. (April 2010). Modeling patient perceptions of service recovery: The effects of perceived fairness on health center repatronage. Social Behavior and Personality An International Journal, vol. 38, no. 3, pp. 395-403.

[33] Palmer, A., Beggs, R., and Keown-McMullan, C. (November 2000). Equity and repurchase intention following service failure. Journal of Services Marketing, vol. 14, no. 6 , pp. 513-528.

[34] Tax, S. S., Brown, S. W., and Chandrashekaran, M. (1998). Customer evaluations of service complaint experiences: Implications for relationship marketing. Journal of Marketing, pp. 60-76.

[35] Whiteman, G. and Mamen, K. (2002). Examining justice and conflict between mining companies and indigenous peoples $\rrbracket$ : Cerro Colorado and the Ngabe-Bugle. Journal of Business and Management, vol. 8, no. 3, pp. 293-330.

[36] Chang, C.-H. and Tu, C.-Y. (2005). Exploring store image, customer satisfaction and customer loyalty relationship: Evidence from Taiwanese hypermarket industry. The Journal of American Academy of Business, vol. 7, no. 2, pp. 197-202.

[37] Tian-Cole S., Crompton, J. L., and Willson, V. L. (2002). An empirical investigation of the relationships between service quality, satisfaction and behavioral intentions among visitors to a wildlife refuge. Journal of Leisure Research, vol. 34, no. 1, pp. $1-24$.

[38] Alam, G. M. and Khalifa, M. T. B. (2009). The impact of introducing a business marketing approach to education: A study on private HE in Bangladesh. African Journal of Business Management, vol. 3, no. 9, pp. 463-474.

[39] Badri, M. A., Attia, S., and Ustadi, A. M. (June 2009). Healthcare quality and moderators of patient satisfaction: testing for causality. International Journal of Health Care Quality Assurance, vol. 22, no. 4, pp. 382-410.

[40] Sixma, H. J., Spreeuwenberg, P. M., and van der Pasch, M. A. (February 1998). Patient satisfaction with the general practitioner: A two-level analysis. Medical Care, vol. 36, no. 2 , pp. $212-229$.

[41] Zapka, J. G., Palmer, R. H., Hargraves, J. L., et al. (January 1995). Relationships of patient satisfaction with experience of system performance and health status. Journal of Ambulatory Care Management, vol. 18, no. 1, pp. 73-83.

[42] Hall, J. A., Milburn, M. A., and Epstein, A. M. (January 1993). A causal model of health status and satisfaction with medical care. Medical Care, vol. 31, no. 1, pp. 84-94.

[43] Bertakis, K. D., Roter, D., and Putnam, S. M. (February 1991). The relationship of physician medical interview style to patient satisfaction. Journal of Family Practice, vol. 32, no. 2, pp. 175-181. 
[44] Soh, G. (1991). Patient satisfaction with physician care. Hawaii Medical Journal, vol. 50, no. 4, pp. 149-152.

[45] Glynn, L., Byrne, M., Newell, J., et al. (October 2004). The effect of health status on patients' satisfaction with out-of-hours care provided by a family doctor co-operative. Family Practice, vol. 21, no. 6, pp. 677-683.

[46] Hair, J. F., Black, W. C., and Anderson, R. E. (2010) Multivariate data analysis, (seveth edition). New Jersey: Prentice Hall.

[47] Agung, I. G. N. (2011). Cross Section and Experimental Data Analysis Using EViews. Singapore: John Wiley \& Sons.

[48] Mehta, S. C., Lalwani, A. K., and Han, S. L. (March 2000). Service quality in retailing: Relative efficiency of alternative measurement scales for different product-service environments. International Journal of Retail \& Distribution Management, vol. 28, no. 2, pp. 62-72.

[49] Wetzels, M., Odekerken-Schröder, G., and van van Oppen, C. (2009). Using PLS Path Modeling for Assessing Hierarchical Construct Models: Guidelines and Empirical Illustration. MIS Q., vol. 33, no. 1, p. 177.

[50] Chin, W. W. and Newsted, P. R. (1999). Structural equation modeling analysis with small samples using partial least squares. Statistical Strategies for Small Sample Research, vol. 1, no. 1, pp. 307-341.

[51] Boller, C., Wyss, K., Mtasiwa, D., et al. (2003). Quality and comparison of antenatal care in public and private providers in the United Republic of Tanzania. Bulletin of the World Health Organization, vol. 81, no. 2, pp. 116-122.

[52] Andaleeb, S. S. (March 2000). Public and private hospitals in Bangladesh: service quality and predictors of hospital choice. Health Policy and Planning, vol. 15, no. 1, pp. 95-102.

[53] Baltussen, R. M. P. M., Yé, Y., Haddad, S., et al. (March 2002). Perceived quality of care of primary health care services in Burkina Faso. Health Policy and Planning, vol. 17, no. 1, pp. 42-48.

[54] van Duong, D., Binns, C. W., Lee, A. H., et al. (December 2004). Measuring clientperceived quality of maternity services in rural Vietnam. International Journal for Quality in Health Care, vol. 16, no. 6, pp. 447-452. 